\title{
TOURISTIC DESTINATIONS AND COASTAL CITIES: EVALUATION OF THE INTEGRALLY PLANNED CENTER LOS CABOS, MEXICO FORTY YEARS FROM ITS FOUNDATION
}

\author{
A. MONTAÑO, A. IVANOVA, I. RODRÍGUEZ, J. PÉREZ \& J. MARTINEZ \\ Universidad Autónoma de Baja California Sur, México.
}

\begin{abstract}
Tourism constitutes the more dynamic activity in some coastal areas of Mexico. This paper has as a goal to describe and analyse touristic development and to value its economic, environmental and social impact in the coastal area of the "Integrally Planned Center of Los Cabos". Descriptive analytic statistical techniques are applied, based on the methodology of indicators of sustainable development for touristic destinations of the World Tourism Organization. The research descriptive considering two analysis periods: the year 2000, when the destination reaches maturity or consolidation, and 2015, year that represents an inflection point in the touristic, economic and social matters, this because of the effects of the "Odile" hurricane, situation that propitiate a relative process of resilience in Los Cabos. The document incorporates three sections; first the analytic and contextual framework is exposed which describes the Los Cabos evolution since its creation as an international touristic destination and the impact that such activity has propitiated on the local sustainable development in the coastal touristic cities belonging to the conurbation of San Jose del Cabo-Cabo San Lucas. Afterwards, we present the methodology and techniques on which the research is based on, highlighting the calculation of the touristic competitiveness indicators, and urban, social and environmental development. In the third section, the results refer that-economically- the destinations has reached certain competitiveness, however, the urban, social and environmental indicators in the cities being studied, showed a relative regression on the comparative evaluation of 2000 and 2015.
\end{abstract}

Keywords: coastal areas, los cabos, touristic sustainability indicators.

\section{INTRODUCTION}

One of the most significant challenges facing tourism planning and management in coastal cities is associated with the achievement of results that relate the models of sustainable tourism development with the private use of natural resources put into value

Today, the Municipality of Los Cabos is a consolidated international tourist destination, a situation that has led to a great economic growth in the region of the extreme south of the peninsula of Baja California. However, like other tourist-coastal cities in Mexico, this destination is characterized by a high spatial segregation, with marked differences in access and availability of public services and urban infrastructure, social marginalization and low identity and rootedness of immigrants to the region [1]. The coastal cities that concentrate the tourist attraction in the Municipality of Los Cabos are Cabo San Lucas, San José del Cabo and the so-called tourist corridor that links both cities, leaving out of this development the northern and rural areas of the Municipality. The disorderly growth experienced by these cities and their conurbation has led to the marginalization of large sectors of the population. For example, more than $30 \%$ of households do not have basic urban services in contrast to the exclusivity of the classification of this destination at international level, which represents a major challenge for the future competitiveness of tourism in Los Cabos [2]. 
In this context, the objectives of this paper are to describe and analyze the tourist development and to evaluate its economic, environmental and social influence in the coastal cities of the municipality of Los Cabos. The first part of the document sets out the methodology of the research, followed by presentation of demographic, economic and tourist indicators that show the impact that tourism has generated in the area. The third section presents the results and the evaluation of 26 sustainable tourism development indicators applied to Los Cabos for the years 2000 and 2015. The results - according to the methodology of the WTO - are interpreted from five different approaches: quality of life, tourism competitiveness, institutional development, urban development and environmental sustainability.

\section{METHODOLOGY}

The methodological framework of this article is based on the UNWTO's "Practical Guide for the Development and Use of Sustainable Tourism Indicators" [3]. This is complemented by the information obtained by consulting experts in research topics, in order to validate the importance of each indicator in Los Cabos. The UNWTO sets out a very broad set of criteria for the selection of sustainability indicators to be considered in a tourist destination, a part of these was selected to be applied in the case of Los Cabos. Firstly, the relevance of the most important problems associated with destination planning and management was considered. A second aspect was the viability of its generation and use, as well as the availability of information from official sources (frequently periodic), in addition to simplicity and ease of interpretation. These criteria were taken into account to establish the universe of 26 indicators that are presented in this paper and refer to the case of tourism in the coastal cities of San José del Cabo, Cabo San Lucas and the tourist corridor.

The selected indicators were classified into five broad areas, which - according to the group of experts - correspond to the factors and areas in which tourism (with associated services) generates impacts on sustainable development in the area of study. The research is descriptive, at the same time as the source of information was documentary, based on official sources, highlighting: INEGI [4], DATATUR [5], Secretary of Tourism, as well as some governmental instances at local level, such as: Municipal Institute of Planning Los Cabos (IMPLAN) [6], Los Cabos Drinking Water Operator (OOMSAPALC) [7] and Los Cabos City Council [8]. In addition, information was provided by various business organizations, such as Business Coordinating Council of Los Cabos, Hotel Association and Timeshare Units Association, among others.

The areas considered for the ranking of indicators are:

1. Quality of life: its objective is to measure the benefits generated by the tourist activity in the destination, in particular in the resident population.

2. Tourism competitiveness: it includes the indicators that allow to evaluate the tourist activity and to compare, at national and international level, the competitiveness of the destination.

3. Institutional Development: they are related to the measurement of the financial capacity and administrative efficiency of the local authority, to face the challenges posed by the urban and tourist development of the municipality.

4. Urban development: they evaluate the functioning and efficiency of the city and the public services granted by the municipality; allow establishing if the population has the adequate coverage of public services, housing and regional urban infrastructure.

5. Environmental sustainability: they allow measuring the impact of the urban-tourist activity of the destination on the environment of the region. 
Table 1: Ranking of values of sustainable tourism indicators.

\begin{tabular}{|c|c|c|c|c|}
\hline \multirow[b]{2}{*}{ Area } & \multirow[b]{2}{*}{ Core topics } & \multicolumn{3}{|c|}{$\begin{array}{l}\text { Parameter or reference } \\
\text { standart }\end{array}$} \\
\hline & & $\begin{array}{l}\text { Sustain- } \\
\text { able }\end{array}$ & Preventive & $\begin{array}{l}\text { Cor- } \\
\text { rective }\end{array}$ \\
\hline \multirow{6}{*}{ 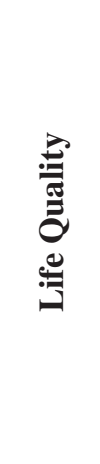 } & $\begin{array}{l}\text { 1. Housing connected to the potable water network/ } \\
\text { total }(\%)\end{array}$ & $>80 \%$ & {$[50,80]$} & $<50$ \\
\hline & 2. Wastewater treatment capacity $(\%)$ & $>60$ & {$[40,60]$} & $<40$ \\
\hline & $\begin{array}{l}\text { 3. Educational expenditure / students enrolled, } \\
\text { basic education (millions } \$ M X N \text { per pupil) }\end{array}$ & $>200$ & {$[130,200]$} & $<130$ \\
\hline & $\begin{array}{l}\text { 4. Resources for health (doctors per } 1000 \\
\text { population) }\end{array}$ & $>1.5$ & {$[1,1.5]$} & $<1$ \\
\hline & $\begin{array}{l}\text { 5. Incidence of property offenses per } 1000 \\
\text { population }\end{array}$ & $<25$ & {$[25,30]$} & $>30$ \\
\hline & 6. Economically active population /total (\%) & $>55$ & {$[35,55]$} & $<35$ \\
\hline \multirow{4}{*}{ 童 } & 7. Average Occupancy Factor (\%) & $>45$ & {$[30,45]$} & $<0.3$ \\
\hline & $\begin{array}{l}\text { 8. Increase in the annual supply of rooms } \\
\text { (number of rooms) }\end{array}$ & $<1500$ & {$[1500,2000]$} & $>2000$ \\
\hline & 9. Average tariff rate in GT and 5 stars (\$US) & $>135$ & {$[100,135]$} & $<100$ \\
\hline & $\begin{array}{l}\text { 10. Matrix of supply by category and type of } \\
\text { operation. Core Indicator: \% of supply in All } \\
\text { Inclusive of } 4^{*} \text { or less/total supply }(\%)\end{array}$ & $<20$ & {$[20,35]$} & $>35$ \\
\hline \multirow{4}{*}{ 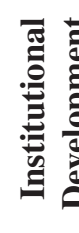 } & 11. Own income/ Total (\%) & $>50$ & {$[20,40]$} & $<20$ \\
\hline & $\begin{array}{l}\text { 12. Municipal public works / total expenditure } \\
\text { (\% without debt) }\end{array}$ & $>11$ & {$[2,10]$} & $<2$ \\
\hline & 13. Current expenditure/total expenditure (\%) & $<30$ & {$[30,45]$} & $>50$ \\
\hline & 14. Public Municipal Investment (\$ MXN) & $>8000$ & {$[6000,8000]$} & $<6000$ \\
\hline \multirow{6}{*}{ 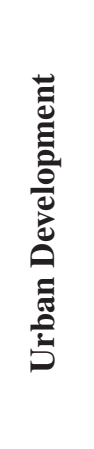 } & $\begin{array}{l}\text { 15. Inventory of territorial reserve en urban zones/5 } \\
\text { years }(\%)\end{array}$ & $>40$ & {$[0,40]$} & $<0$ \\
\hline & $\begin{array}{l}\text { 16. Number of houses with earth floor, walls and roof } \\
\text { of sheet, cardboard and waste materials / total of } \\
\text { houses }(\%)\end{array}$ & $<3$ & {$[3,7]$} & $>7$ \\
\hline & 17. Need for housing / existing housing (\%) & $<11$ & {$[11,16]$} & $>16$ \\
\hline & 18. Surface of green areas ( $\mathrm{m}^{2}$ per inhabitant) & $>5$ & {$[0,5]$} & $<0$ \\
\hline & 19. Paving coverage / total roads $(\%)$ & $>60$ & {$[30,60]$} & $<30$ \\
\hline & $\begin{array}{l}\text { 20. Composite indicator on the lag of urban } \\
\text { equipment }(\%)\end{array}$ & $<50$ & {$[50,70]$} & $>70$ \\
\hline
\end{tabular}

(Continued) 


\begin{tabular}{|c|c|c|c|c|}
\hline \multirow[b]{2}{*}{ Area } & \multirow[b]{2}{*}{ Core topics } & \multicolumn{3}{|c|}{$\begin{array}{l}\text { Parameter or reference } \\
\text { standart }\end{array}$} \\
\hline & & $\begin{array}{l}\text { Sustain- } \\
\text { able }\end{array}$ & Preventive & $\begin{array}{l}\text { Cor- } \\
\text { rective }\end{array}$ \\
\hline \multirow{6}{*}{ 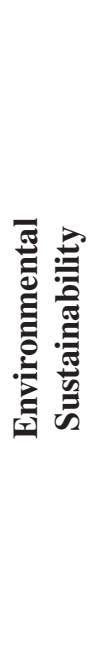 } & $\begin{array}{l}\text { 21. Total annual average recharge - value of the natu- } \\
\text { ral discharge committed - volume of groundwater } \\
\text { granted and registered in the REPDA (million m3/ } \\
\text { year) (availability of drinking water in the San } \\
\text { José del Cabo aquifer) }\end{array}$ & $>0.5$ & {$[-6,-0.5]$} & $<-6$ \\
\hline & $\begin{array}{l}\text { 22. Water consumption per capita (liters / day / inhab- } \\
\text { itant) }\end{array}$ & $<317$ & {$[317,350]$} & $>350$ \\
\hline & 23. Water supply per room (liters per day) & $<1260$ & {$[1260,1600]$} & $>1600$ \\
\hline & 24. Generation of solid waste per capita (kg per day) & $<0.65$ & {$[0.65,1]$} & $>1$ \\
\hline & $\begin{array}{l}\text { 25. Solid waste collected from other sources such as } \\
\text { hotels, restaurants and commerce, per visitor (kg } \\
\text { / visitor / day) (Generation of solid waste in tour- } \\
\text { ism by hotel room) }\end{array}$ & $<0.25$ & {$[0.25,0.25]$} & $>0.5$ \\
\hline & $\begin{array}{l}\text { 26. Area with vegetation cover / total area to be used } \\
\text { (Natural vegetation cover in useable areas) (in \%) }\end{array}$ & $>0.5$ & {$[0.2,0.4]$} & $<0.2$ \\
\hline
\end{tabular}

The evaluation of each of the indicators was weighted based on qualification obtained according to the reference parameter or standard. The results generated for 2015 was compared to those of 2000. The year 2000, was selected because that's when Los Cabos was consolidated as an international tourist destination. The year 2015 was taken into account for two reasons: the availability of most recent official statistics and because in this year initiated a process to create resilience because of the disasters caused by hurricane "Odile" (September 2014). The comparison is expressed in a system of traffic lights that reflects three levels of performance: state of sustainability, in process of sustainability, and sustainability at risk.

\section{CONCEPTUAL ASPECTS OF TOURISM}

It is considered that tourism is one of the main sources of wealth and economic growth in some regions, but also generates impacts on environment, social issues and cultural resources of the receiving community. In order to minimize negative impacts, a number of international organizations, including the World Tourism Organization (UNWTO) and a number of specialists in the field, have expressed their support to development model framed in the concept of "sustainable tourism". This must consider the interrelationship between tourism development and the sustainability of the environment. UNWTO stresses that the guidelines for tourism development, in relation to sustainable management practices, apply to all forms and / or segments of tourism. The principles of sustainability refer to the environmental, economic and socio-cultural aspects of tourism development, and a balance must exist between the three dimensions to ensure sustainability in the long term.

The relationship between tourism development and environmental issues has been analyzed under two main approaches: firstly, tourism as an alternative for economic and socially 
sustainable development; Secondly, tourism as the origin of socio-environmental deterioration processes [9]. In this context, it should be considered that tourism can generate adverse effects on the environment, but this economic sector is also an opportunity for local development. Tourism explores regional vocations, at the same time fostering and integrating other sectors to the local and regional economic development. Tourism can generate multiplying effects on local economy, fostering value chains based on natural resources [10].

As mentioned above, the effects of tourism (as an economic activity) can positively or negatively affect a destination, but it will depend on the quality of the territorial planning (and the existence of adequate public policies). To obtain positive and tangible for the society results, the multiple dimensions included in sustainable tourism development must be incorporated (economic, social, environmental, cultural and institutional), because only balancing these dimensions would be possible to guarantee long-term sustainability [11].

However, attempting a sustainable tourism activity may not make sense without the existence of objective ways of assessing sustainability. The UNWTO states that in order to achieve an efficient process of planning and management of tourism, and to assess its evolution, it is advisable to use sustainability indicators that identify changes and possible alarm signals over time. These indicators provide sufficient and reliable information to define when it is necessary to modify public policies or to implement new actions. In addition, with these indicators, it is possible to generate a set of data on actual situation of tourism development, particularly regarding aspects related to sustainability. This database should facilitate the decision-making performed by various stakeholders involved in planning, so that the sustainable practices define the future actions.

According to UNWTO, the indicators that refer to the development of sustainable tourism correspond to the set of formally selected data regularly used to measure the changes caused by the development and management of tourist activities in a locality. These can serve as instrument to detect repercussions of these changes on tourist structures and on external factors influencing tourism. Through the mentioned sustainability indicators, it is possible to synthesize previously selected information, which facilitates processing and analysis of data in order to implement objective and effective policies. At the same time, instruments and programs focused on solving problems and recognizing areas of risk, can be established or designed.

At present, the development of coastal cities with a tourist vocation in Mexico faces a series of conflicts due to factors as poor planning and territorial organization, high immigration processes, heavy lags in social infrastructure, lack of public policies to control the development of tourism, and irregular settlements. Added to this, the authorities adopt decisions with political criteria rather than social criteria. However, the most important factor in tourism is the prioritization of the value of natural resources to the detriment of cultural, social and environmental aspects, which - from our perspective - represent the true capital of the tourist destinations.

The intensive use of the coasts, particularly when it is oriented to the second-home property market or mega tourist developments (tourist enclaves) framed in the "sun and beach" model, has been an important topic of research, controversies and demands. That is because the growing spatial intervention by the tourism and real estate sectors has contributed (to a great extent) to disrupting the sustainable development of coastal cities [12].

In the last decades, mass tourism or "Fordism model" has consolidated in the tourist destinations of sun and beach in Mexico, focusing on those territorial spaces with "natural capital" like beaches, vegetation, flora, fauna, as well as areas of privacy or remoteness from large cities. That generated accelerated growth of tourist enclaves along the coasts, affecting the 
environmental, cultural and social value of coastal cities such as Cancun, Acapulco, Puerto Vallarta and Los Cabos [13].

The creation of the National Tourism Fund (FONATUR) in 1974 focused on the development of tourism projects based on the "Integrally Planned Centers" (CIP) model, whose strategy was to create tourist complexes and provide them with basic infrastructure in relatively remote coastal areas, with little economic and demographic development, but with a great availability of natural resources. In this way, seven CIPs arose, presenting Cancun and Los Cabos the most important economic results [14], based on "sun and beach" tourism.

\section{SOCIAL CONTEXT AND TOURISM ACTIVITY INDICATORS IN LOS CABOS}

From the political-administrative point of view, Los Cabos is located at the southern end of the state of Baja California Sur. Unlike the rest of the state, its rapid economic growth (supported by investments in tourism and associated services) has led to a rapid increase in the number of inhabitants (between 1980 and 2015 the population increased by 1.405\%) [15] that represents $40.4 \%$ of the state population. This situation has caused heavy lags in urban and social infrastructure, as well as marginalization and poverty. In fact, based on the 20152018 Municipal Development Plan [10], in 2015, 28.5\% of the population was in poverty, $40.3 \%$ were vulnerable due to social deficiencies, $2.6 \%$ were vulnerable to income, $5.6 \%$ were in extreme poverty and only $28.6 \%$ of the population was non-poor and not vulnerable.

Because of the aforementioned economic growth, the social inequalities to access to the minimum wellbeing generate a conspicuous contrast between the exclusive mega resorts and big hotels of the tourist zone associated with the coast and oriented to isolate the tourist, and the lack of urban and social infrastructure in poor colonies and irregular settlements. This requires the urgent creation of mechanism for distribution of the economic benefits of tourism, thus reducing the inequalities and making the tourist cities of Los Cabos more homogenous, equitable, comprehensive and democratic.

In contrast, tourism has also favored job creation. In fact, in 2014 the population employed in the tourist activity in Los Cabos (considering the classification of INEGI of jobs in the sector of lodging and preparation of food and beverages) represented 30.5\% of the economically active population (EAP) of the entire state of Baja California Sur.

Table 2: Demographic and Demand Indicators (Source: DATATUR, 2015)

\begin{tabular}{llllll}
\hline Year & $\begin{array}{l}\text { Population of } \\
\text { Los Cabos }\end{array}$ & $\begin{array}{l}\text { EAP of } \\
\text { Tourism }\end{array}$ & $\begin{array}{l}\text { Foreign } \\
\text { Tourists }\end{array}$ & $\begin{array}{l}\text { Domestic } \\
\text { Tourists }\end{array}$ & Total Tourists \\
\hline 1980 & 19,117 & n.d. & 39,200 & 70,300 & 109,500 \\
1985 & 29,279 & n.d. & 105,500 & 134,800 & 240,300 \\
1990 & 43,920 & 3,348 & 228,000 & 77,167 & 305,167 \\
1995 & 71,031 & 5,346 & 390,355 & 91,580 & 481,935 \\
2000 & 105,469 & 7,821 & 577,548 & 127,824 & 705,372 \\
2005 & 164,162 & 11,435 & $1,006,963$ & 221,873 & $1,228,836$ \\
2010 & 238,487 & 24,320 & 842,606 & 382,504 & $1,225,110$ \\
2015 & 287,671 & 39,295 & $1,277,250$ & 425,750 & $1,703,000$ \\
\hline
\end{tabular}


It is evident that from an economic and commercial point of view, Los Cabos represents a successful destination, considering how attractive it is for foreign tourists. However, it is necessary to mention that -historically- demand is what marks the increase in the supply of rooms and tourist services. As shown in the attached tables, the ratio of foreign and national visitors was 3 to 1 in 2015 (in 2005, prior to the crisis in US property markets, this ratio was 4.5 to 1). This situation has been a common denominator in Los Cabos and one of the factors that have led to large investments in hotel infrastructure, commerce and services to meet growing demand.

Based on available information, we recognize a series of factors that have been basic in tourism development and that have influenced the competitiveness of Los Cabos:

1. The closeness to the market with states of greater purchasing power in the United States, such as the western and southwestern states, particularly California.

2. The development of a hotel infrastructure and time share units of high quality and market value, as well as a wide range of properties for second residence of foreigners.

3. Natural resources that can be used to produce value.

4. The installation of basic external economies in the competitiveness of the destination, such as the airport, telecommunications services, roads, marinas, marketing and promotion programs (expenditure-for the most part is covered by the federal government of Mexico).

5. The peso / dollar exchange rate has always been a variable that favors foreign tourists.

6. Unlike other economic sectors, tourism, commerce and the services associated to their supply do not require a great work specialization, which makes labor costs relatively low.

\section{RESULTS}

When comparing the indicators of sustainable tourism for the two evaluation periods, it is clear that - with the exception of the area of tourism competitiveness - Los Cabos presents a setback in the areas of quality of life, institutional development and urban development. As can be observed in Table 4, some indicators went from a range of: "in process of sustainability" to "sustainability at risk". For example, the decline in the indicator for municipal public

Table 3: Tourist Indicators of Los Cabos, (Source: DATATUR, 2015).

\begin{tabular}{|c|c|c|c|c|c|}
\hline Year & $\begin{array}{l}\text { Rooms } \\
\text { Inventory }\end{array}$ & $\begin{array}{l}\text { Hotel } \\
\text { Occupancy } \\
(\%)\end{array}$ & $\begin{array}{l}\text { Economic } \\
\text { Income (\$US) }\end{array}$ & $\begin{array}{l}\text { Total } \\
\text { International } \\
\text { Flights }\end{array}$ & $\begin{array}{l}\text { Total National } \\
\text { Flights }\end{array}$ \\
\hline 1980 & 544 & 61.90 & $\$ 20,948.0$ & 907 & 380 \\
\hline 1985 & 1,219 & 53.00 & $\$ 56,204.0$ & 1,373 & 696 \\
\hline 1990 & 2,531 & 49.00 & $\$ 148,885.0$ & 2,957 & 1762 \\
\hline 1995 & 3,710 & 61.40 & $\$ 245,492.0$ & 4,480 & 998 \\
\hline 2000 & 4,842 & 59.70 & $\$ 378,628.0$ & 5,961 & 1714 \\
\hline 2005 & 7,849 & 64.10 & $\$ 779,940.0$ & 9,955 & 3,548 \\
\hline 2010 & 11,762 & 62.20 & $\$ 690,373.0$ & 8,599 & 4,793 \\
\hline 2015 & 12,465 & 65.43 & n. d. & 13,268 & 5,598 \\
\hline
\end{tabular}


investment per capita, as well as the high ratio of current expenditure to total expenditure, is striking. Even though the municipality's revenues reflect a good index of own income with respect to total revenues (between 2010 and 2015 municipal revenues increased from $\$ 1,041.4$ to 1,614 .1 million pesos, reflecting a nominal increase of 55\%), the largest part is intended for current expenditure, transfers and subsidies. In terms of urban development, there are lags and deficits in urban infrastructure, with high demand for basic education, health and recreation. The precarious housing index rises from 6 to $9.5 \%$, as well as the index that values the demand for new housing. There are irregular settlements that accelerate the processes of marginalization by lack of infrastructure, which also leads to a deterioration of the environment coupled with the fact that the municipality doesn't have territorial reserves for properly planned urban settlements.

The critical variables that endanger the sustainability of the destination are from the environmental area, a situation frequently reflected in the coastal cities with tourist vocation in Mexico. The indicators express the problems and deficits that exist in the availability of drinking water, a factor that - according to the Mexican Institute of Competitiveness (IMCO) and IMPLAN - limits the possible growth of tourism in Los Cabos. At the same time, the final disposal of solid waste and the management of wastewater also register deficits, since there is not enough coverage of these services, but it is no public investments to overcome these problems. There is also a decrease in the natural vegetation cover in areas exploited, as an economistic and short-term criterion has prevailed over the environment and natural resources.

Table 4: Indicators of sustainable tourism in Los Cabos.

\begin{tabular}{|c|c|c|c|c|c|}
\hline Area & Core topics & $\begin{array}{l}\text { Year } \\
2000\end{array}$ & $\begin{array}{l}\text { Rank- } \\
\text { ing }\end{array}$ & $\begin{array}{l}\text { Year } \\
2015\end{array}$ & Ranking \\
\hline \multirow{6}{*}{ 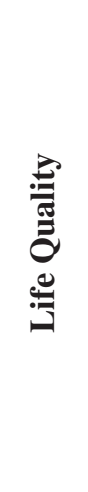 } & $\begin{array}{l}\text { 1. Housing connected to the potable water } \\
\text { network / total }(\%)\end{array}$ & $79 \%$ & & $82 \%$ & \\
\hline & 2. Wastewater treatment capacity $(\%)$ & $45 \%$ & & $51 \%$ & \\
\hline & $\begin{array}{l}\text { 3. Educational expenditure / students en- } \\
\text { rolled, basic education (millions \$MXN } \\
\text { per pupil) }\end{array}$ & $\$ 225$ & & $\$ 185$ & \\
\hline & $\begin{array}{l}\text { 4. Resources for health (doctors per } 1000 \\
\text { population) }\end{array}$ & $1.5 \%$ & & $0.98 \%$ & \\
\hline & $\begin{array}{l}\text { 5. Incidence of property offenses per } 1000 \\
\text { population }\end{array}$ & 20 & & n.d. & \\
\hline & 6. Economically active population / total (\%) & $29 \%$ & & $47 \%$ & \\
\hline \multirow{4}{*}{ 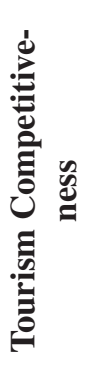 } & 7. Average occupancy factor (\%) & $59 \%$ & & $64 \%$ & \\
\hline & $\begin{array}{l}\text { 8. Increase in the annual supply of rooms } \\
\text { (number of rooms) }\end{array}$ & 521 & & 1,110 & \\
\hline & $\begin{array}{l}\text { 9. Average tariff rate in GT and } 5 \text { stars } \\
\text { (\$US) }\end{array}$ & 165 & & 260 & \\
\hline & $\begin{array}{l}\text { 10. Matrix of supply by category and type of } \\
\text { operation. Core Indicator: } \% \text { of supply in } \\
\text { All Inclusive of } 4 * \text { or less / total supply (\%) }\end{array}$ & $13 \%$ & & $19 \%$ & \\
\hline
\end{tabular}


Table 4: (Continued)

\begin{tabular}{|c|c|c|c|c|c|}
\hline Area & Core topics & $\begin{array}{l}\text { Year } \\
2000\end{array}$ & $\begin{array}{l}\text { Rank- } \\
\text { ing }\end{array}$ & $\begin{array}{l}\text { Year } \\
2015\end{array}$ & Ranking \\
\hline \multirow{4}{*}{ 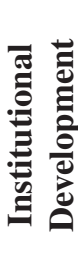 } & 11. Own income/ Total (\%) & $60.3 \%$ & & $58.4 \%$ & \\
\hline & $\begin{array}{l}\text { 12. Municipal public works / total } \\
\text { expenditure ( } \% \text { without debt) }\end{array}$ & $11.1 \%$ & & $8.6 \%$ & \\
\hline & $\begin{array}{l}\text { 13. Current expenditure / total expenditure } \\
(\%)\end{array}$ & $74.0 \%$ & & $75.0 \%$ & \\
\hline & 14. Public Municipal Investment (\$ MXN) & $\$ 739.2$ & & $\$ 432$ & \\
\hline \multirow{6}{*}{ 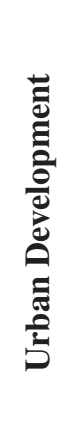 } & $\begin{array}{l}\text { 15. Inventory of territorial reserve en urban } \\
\text { zones / } 5 \text { years }(\%)\end{array}$ & $2 \%$ & & $0 \%$ & \\
\hline & $\begin{array}{l}\text { 16. Number of houses with earth floor, walls } \\
\text { and roof of sheet, cardboard and waste } \\
\text { materials / total of houses }(\%)\end{array}$ & $6.2 \%$ & & $9.5 \%$ & \\
\hline & 17. Need for housing / existing housing (\%) & $16 \%$ & & $19 \%$ & \\
\hline & 18. Surface of green areas ( $\mathrm{m}^{2}$ per inhabitant) & 4.1 & & 2.17 & \\
\hline & 19. Paving coverage / total roads $(\%)$ & $32 \%$ & & $41 \%$ & \\
\hline & $\begin{array}{l}\text { 20. Composite indicator on the lag of urban } \\
\text { equipment }(\%)\end{array}$ & $38 \%$ & & $45 \%$ & \\
\hline \multirow{6}{*}{ 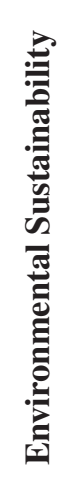 } & $\begin{array}{l}\text { 21. Availability of drinking water in the San } \\
\text { José del Cabo aquifer }\end{array}$ & $-5.24 \%$ & & $-6.90 \%$ & \\
\hline & $\begin{array}{l}\text { 22. Water consumption per capita (liters/day } \\
\text { / inhabitant) }\end{array}$ & 220.7 & & 369.0 & \\
\hline & 23. Water supply per room (liters per day) & 1,574 & & 3,423 & \\
\hline & $\begin{array}{l}\text { 24. Generation of solid waste per capita } \\
(\mathrm{kg} \text {. per day) }\end{array}$ & 1.13 & & 5.2 & \\
\hline & $\begin{array}{l}\text { 25. Generation of solid waste in tourism by } \\
\text { hotel room }\end{array}$ & 14.5 & & 21.4 & \\
\hline & $\begin{array}{l}\text { 26. Natural vegetation covers in useable areas } \\
(\%)\end{array}$ & $60 \%$ & & $50 \%$ & \\
\hline
\end{tabular}

$\square$ Sustainable level $\square$ In process of sustainability $\square$ Sustainability at risk

The results of the area of tourist competitiveness generate economic information related to the performance of the tourist activity. The data obtained reflect that in the period between 2000 and 2015, there was a considerable increase in the hotel, timeshares and properties for second residence. The hotel occupancy rate exceeds the national average, being above other destinations of the same category, such as Cancun and Puerto Vallarta, registering average rates that place Los Cabos as an exclusive international destination and with an important supply for high-income foreign tourism. The supply focuses on hotels and resorts of Gran Tourism and Five Star categories. Therefore, the indicators of tourism competitiveness place this destination at the sustainable level and of great success for the investors and economic agents of the area. However, it's worth mentioning that the pending task is located in the indicators that measure or evaluate the areas of environmental sustainability and urban development. 


\section{CONCLUSIONS}

The analysis based on the indicators of tourist sustainability in Los Cabos, confirms that, the destination has experienced a great dynamism and growth in tourism. The increase in the supply of rooms, timeshare units and second homes residence, reflect the boom that this tourism center experienced in the international market. This entails constant raise of demand and investments that place Los Cabos as a competitive tourist destination with significant multiplier effect on sectors directly related to this economic activity (e.g. trade, services, transport and construction). However, despite the economic strength of tourism today, this sector has not been able to integrate into the local economic development of the area. It is recommendable for local authority to design development programs and to foster a greater linkage of local productive systems with tourism, considering that this sector is the predominant economic activity in the coastal cities of Los Cabos.

The accelerated urban growth, because of the impetus given by the federal government to Los Cabos since its creation as an integrally planned center in 1976, has created a series of problems related to environmental sustainability, urban development and social segregation. The indicators that evaluate these areas do not present the general signs of a positive evolution. In the reference years 2000 and 2015, most of the indicators of urban and environmental sustainability are in the range of parameter of sustainability at risk (a difference of the positive results presented by the item related to tourism competitiveness). The disorderly growth in the urban areas of San José del Cabo and San Lucas, resulting from the boom in tourism and real estate, has had a strong impact on the reduction of the water resources needed by tourist cities (for tourism infrastructure, public services, urban infrastructure and economic growth). The results show that between 2000 and 2015, these variables represent a challenge and jeopardize the competitiveness of the destination in the long term.

The analysis and the results presented here, can be used by local authorities to generate proposals for public policies, tending to reduce (or at least attenuate) the problems of urban development and environment, recognizing that tourism as an important economic sector, but it's development is based on the natural resources.

Forty years have passed since the creation of the CIP in Los Cabos, economic growth is evident, from a relatively isolated area, with small towns focused on self-consumption the area evolved to cities with a dynamic economy, recognized as international tourism centers. However, critical variables such as urban development and environmental sustainability (which were not included in the CIP Master Plan in 1976) threaten the development of this already consolidated destiny. According to the theory, these must be reconsidered. How long will the supportive capacity of the destiny withstand the pressure to the critical variables? What kind of actions, works and services are required for the rethinking of the model applied in Los Cabos? These questions are open and all local stakeholders have to be part in finding the right answer.

\section{REFERENCES}

[1] Montaño, A. \& Pérez, J.C., Diversificación de la oferta a partir del turismo de naturaleza: un análisis de la percepción de los actores del desarrollo económico turístico en Los Cabos, en Ivanova, A. \& Serrano, R. (Coord): Areas Naturales Protegidas: Vías para un desarrollo sustentable, ed. CONANP-SEMARNAT pp. 169-196, 2015.

[2] IMCO, Instituto Mexicano para la Competitividad, Nueva política turística para recuperar la competitividad del sector y detonar el desarrollo regional, IMCO: México, D.F, 2013. 
[3] OMT. Indicadores de Desarrollo Sostenible para Los Destinos Turísticos, Vol. 1, Madrid España, 2005.

[4] INEGI., Anuario Estadístico y Geográfico de Baja California Sur, La Paz Baja California Sur México, 2016.

[5] DATATUR., Compendio estadístico del sector Turismo de México, Secretaría de Turismo, México D.F, 2015.

[6] IMPLAN, Segunda Actualización del Plan Director de Desarrollo Urbano San José del Cabo y Cabo San Lucas, San José del Cabo, México, 2013.

[7] OOMSAPAS Los Cabos., Indicadores de Gestión, available at http://aguapotabledeloscabos.gob.mx/ (accesed 20 February 2017)

[8] XII Ayuntamiento de Los Cabos., Plan de Desarrollo Municipal Los Cabos 2015-2018, San José del Cabo, México, 2017.

[9] Macário de Oliveira, V., Pasa Gómez, C. \& Ataide Cândido, G., Indicadores de Sustentabilidad para La Actividad Turística Una propuesta de monitoreo usando criterios de análisis. Estudios y Perspectivas en Turismo, 22, pp. 177-197, 2013.

[10] Poudel, S., Nyaupane, G.P. \& Budruk, M., Stakeholders' perspectives of sustainable tourism development: a new approach to measuring outcomes. Journal of Travel Research Sage Journal, 55(4), pp. 465-480.

https://doi.org/10.1177/0047287514563166

[11] Namhyun, K., HakJun, S. \& Hyun, P.J., The relationship among tourism, poverty, and economic development in developing countries: A panel data regression analysis. Tourism Economics Sage Journal, 22(6), pp. 1174-1190, 2016. https://doi.org/10.1177/1354816616669038

[12] Rodrigo, H., Herrera, C., Carreño, M. \& Casaubon, C., La Urbanización del borde costero en la región de Valparaíso: entre el ideal de justicia espacial y la inequidad socioterritorial. En las costas del neoliberalismo Naturaleza, Urbanización y Producción Inmobiliaria: experiencias en Chile y Argentina, pp. 238-259, 2016.

[13] Fitch Ratings., Municipio de Los Cabos, Baja California Sur reporte de calificación, available at http://www.fitchratings.mx/default.aspx (accesed 20 February 2017)

[14] Montaño, A., Pérez, J.C. \& de la, O.V., Reposicionamiento para destinos turísticos consolidados: el caso de Los Cabos. México, Cuadernos de Turismo, 33, pp. 271-295, 2014.

[15] INEGI, Instituto Nacional de Estadística y Geografía. Directorio Estadístico Nacional de Unidades Económicas, available at http://www.inegi.org.mx/default.aspx (accesed 20 February 2017) 